\title{
Using mechanical clearing and goat grazing for restoring understorey plant diversity of embankments in the Rhône valley (southern France) Cannelle MOINARDEAU ${ }^{\mathrm{a} *}$, François MESLEARD ${ }^{\mathrm{a}, \mathrm{b}}$, Hervé RAMONE ${ }^{\mathrm{a}}$, Thierry DUTOIT ${ }^{\mathrm{a}}$
}

\author{
a Institut Méditerranéen de Biodiversité et Ecologie, UMR CNRS-IRD, Avignon Université, Aix-Marseille Université, IUT d'Avignon, 337 chemin \\ des Meinajariés, Site Agroparc BP 61207, 84911 Avignon, cedex 09, France. \\ b Institut de Recherche de la Tour du Valat, Le Sambuc, 13200 Arles, France \\ *corresponding author, e-mail: cannelle.moinardeau@gmail.com
}

How to cite: Moinardeau C., Mesléard F., Ramone H., Dutoit T. 2019. Using mechanical clearing and goat grazing for restoring understorey plant diversity of embankments in the Rhone valley (Southern France). Plant Biosystems - An International Journal Dealing with all Aspects of Plant Biology 0:1-11. doi: $\underline{10.1080 / 11263504.2019 .1686080}$

\section{Abstract}

Consumption by animals remains one of the key points to assess the effectiveness of grazing impacts in woodland for increasing understorey plant diversity. To limit the spread of the brambles and restore understorey plant diversity on an artificial embankment an original system of clearings connected by paths was created by mechanically crushing brambles and allowing them to be grazed by rustic goats. The analysis of the indices of consumption of bramble under GIS has been used to provide an estimation of the volume ingested and an estimation of the effectiveness of the goats. The impacts of three different managements (goat grazing, brush clearing and grazing, clearing and exclusion of grazing) and control without management were then tested during a three-year period. The monitoring of the vegetation on permanent plots provided evidence that goat grazing significantly increased in the short term the species-richness and heterogeneity of herbaceous plants communities, in complement with prior clearing. Thus, the objectives of the managers to open up the area and reduce the bramble cover were achieved, but the prior introduction of goats and the installation of mobile enclosures would be advisable in order to ensure the sustainability of these measures on plant diversity in the long term.

\section{Introduction}

The construction of dams and dykes has for several centuries profoundly disturbed the biodiversity of the European river valleys (Jensen et al. 2006). The artificialization of the river beds may prove irreversible, since the ecological restoration of the environment does not necessarily mean a return to the natural dynamic of the watercourse. These alterations may then result in significant changes in the riverside plant communities (Wasson et al. 1995), in particular where dykes and embankment shave been installed following the construction of channels and hydroelectric installations. On these constructions, the necessity for security needs to detect and prevent, for reasons of security any anomaly, such as infiltrations of water via root systems underground, may require the maintenance of open vegetation, mainly by mechanically clearing or mowing on a regular basis (Nicaise 1996). In contrast, on embankments where security is not a major issue, a natural plant succession may occur and lead to the colonisation of these constructions by woody species. This is the case in particular for embankments located downstream of hydroelectric dams, where the water discharged from the turbines represents less risk than upstream. The opening up of the vegetation and the control of woody species can be searched for other reasons, such as counteracting the refuge effect for wild boar in an agricultural landscape context (Tolon \& Baubet 2010), the wish to maintain the heterogeneity of the vegetation in order to maximise the diversity of the flora and fauna, or create grassland corridors at the scale of the catchment area (Clément \& Maltby 1996). Grazing, according to certain modalities, may then be proposed as a tool for the restoration and conservation of open spaces (meadows, grasslands, clearings, borders, etc.).

Grazing by large herbivores has already been used for a number of years as a management system in numerous semi-natural grassland ecosystems (McNaughton 1985; Gibson et al.1987; Bullock et al. 1994; van Wieren 1995; Bakker 1998; van Wieren \& Bakker 1998; Bokdam \& Gleichman 2000), notably in order to enhance biodiversity (Watkinson \& Ormerod 2001) in the Mediterranean region (Bagella et al. 2016; Seddaiu et al. 2018). Grazing is effective to control encroachment by shrubs as long as appropriate modes of management are applied (Rotherham 
2013; Saatkamp et al. 2017). This 'targeted grazing' (Frost and Launchbaugh, 2003) aims, by introducing a herd for a period and at a time, and on the basis of predetermined patterns of intensity, to meet specific objectives with regard to the management of the vegetation. The quantification of the impact of such a management system on the plants and its adjustment are fairly recent objectives (Ingham 2008), but it has already been shown that grazing, especially by small ruminants often has a positive effect an may be used as a complement to mechanical clearing (Tälle et al. 2016). In the understorey, small ruminants thus consume both herbaceous species, low woody species, the leaves and young shoots of trees, as well as windfall fruits. Trees, thus, provides complementary elements in the diet because of the diversity of the offer (leaves, branches, fruits), (Roudaut et al. 2007), even if their consumption varies during the year (De Simiane 1987). The palatability and appetising quality of the plants are related to the herbivores used (Meuret 2005). The quality and digestibility of the plants consumed varies depending on the herbivores. Finally, the operating mode and the grazing technique used (rotation, mobile enclosures, stocking rate, etc.) also condition the feeding behaviour (intensity of consumption).

Goats are exploratory animals (Langbein et al. 2009; Briefer et al. 2014; Nawroth 2017). They thus appear the best suited domestic herbivores for Mediterranean shrublands or overgrown environments by their ability to consume shrubs (Rogosic et al. 2006). Public demand is growing for eco-grazing via the use of rustic animals, such as shrub clearing by goats, for reasons both practical (ability to operate in terrain that is unsuitable for mechanical clearing) and economic, but also for the 'positive' image that this method of clearing can convey (McGregor 2003). In shrubland, grazing is often associated with mechanical operations (rotary flail, brush clearing, etc.). A prior mechanical opening of the area the first year is almost always recommended, in order to facilitate and simplify the flock's access to the area (CERPAM 2006). Although studies focused on the respective impact of brush clearing and grazing have not always given rise to clear-cut conclusions, works on this topic in European semi-natural grasslands (Tälle et al., 2018) most often show a similar effect of the frequency of slashing in the short term and more uncertain effects in the long term. The reason might be the more rapid change in the vegetation during the first years after the introduction of a new method of management, or changes in the grazing intensity (Lepš 1987). These results however concern European semi-natural grasslands and not Mediterranean shrubland or forest areas. The type of management applied may be more determinant than the intensity applied (Tôth et al. 2016; Batâry et al. 2010). Frequency, however, is also critical factor to consider; repeated slashing during the same year might be favourable for conservation, but not from the economic point of view (Tälle et al. 2018).

The effectiveness of grazing in terms of biodiversity restoration and conservation is strongly linked to the types, volumes and period of plant consumption by herbivores and according to the aim of the study numerous methods have previously been developed to measure the animals' consumption. Direct observation of small bites and the use of chromium oxide markers enable to precisely determine the quantity of dry matter ingested, and thus to respond to zoo-technical questions (calculation of diet), (Meuret et al. 1985). In contrast, the measurement of an index of consumption can provide an overall view of the phyto-volume ingested by the herd, and thus to estimate the effectiveness of the clearing. This method is widely recommended during the monitoring of brush clearing by herds in a natural environment (Etienne et al. 2002). The coupling of this method with remote sensing also enables the spatial quantification and representation, via the Geographical Information System (GIS), of the animals' consumption of plants at the scale of the area grazed (Reinke \& Jones 2006; Köhler et al. 2016).

Several studies concerning the impact and the effectiveness of goat grazing on the understorey vegetation (Elias \& Tischew 2016), and in particular on the brambles (Hendrickson \& Olson 2006; Ingham 2008), have already been carried out. The species with a high growth rate, in particular after cutting or browsing of their tips, such as bramble, often colonise forests disturbed or in the course of succession (Radosevich et al. 2007). Among these studies, few have focused on the comparison of the effects of clearing, grazing and their combination with a non-grazed control plot.

In the present three-year study (2014-2016), we therefore tested the respective impact of an extensive regime of goat grazing without any objective of production, following or not mechanical brush clearing in the form of cleared paths (2012), on the herbaceous vegetation of an embankment covered with natural woody vegetation, situated in the lower Rhone valley, along a river deviation channel. As a complement to the vegetation survey, consumption of brambles was estimated and subsequently mapped by GIS. In order to explain the spatial distribution patterns of the different rates of consumption we tested different variables (i.e. distance from the mobile enclosures and area previously cleared mechanically or not).

We aimed to answer the following questions: 
- Which, between goat grazing, mechanical clearing or a combination of the two, best enhances the composition, richness, diversity and heterogeneity of the herbaceous vegetation?

- What factors best explain the spatial heterogeneity of the goats' consumption of brambles at site scale?

\section{Material \& methods}

\subsection{Study site}

The local climate of the site is Mediterranean, with an annual mean temperature of $15^{\circ} \mathrm{C}$ and total annual precipitation of between 500 and $700 \mathrm{~mm}$. The site (coord. $44^{\circ} 16^{\prime} 41.58^{\prime \prime} \mathrm{N} 4^{\circ} 43^{\prime} 22.65^{\prime \prime} \mathrm{E}$ ) is constituted of the artificial dykes and embankments of the dam and hydroelectric power station of Donzère-Mondragon, located 180 $\mathrm{km}$ south of Lyon and $55 \mathrm{~km}$ north of Avignon, on the lower reaches of the Rhone river (Fig. 1).Constructed between 1948 and 1952 by the Compagnie Nationale du Rhône (CNR), the Donzère-Mondragon canal transports a substantial part of the waters of the Rhone necessary for the hydroelectric power station, over a distance of $33 \mathrm{~km}$ between the towns of Donzère and Mondragon, in the alluvial plain of Tricastin (Fig. 1).

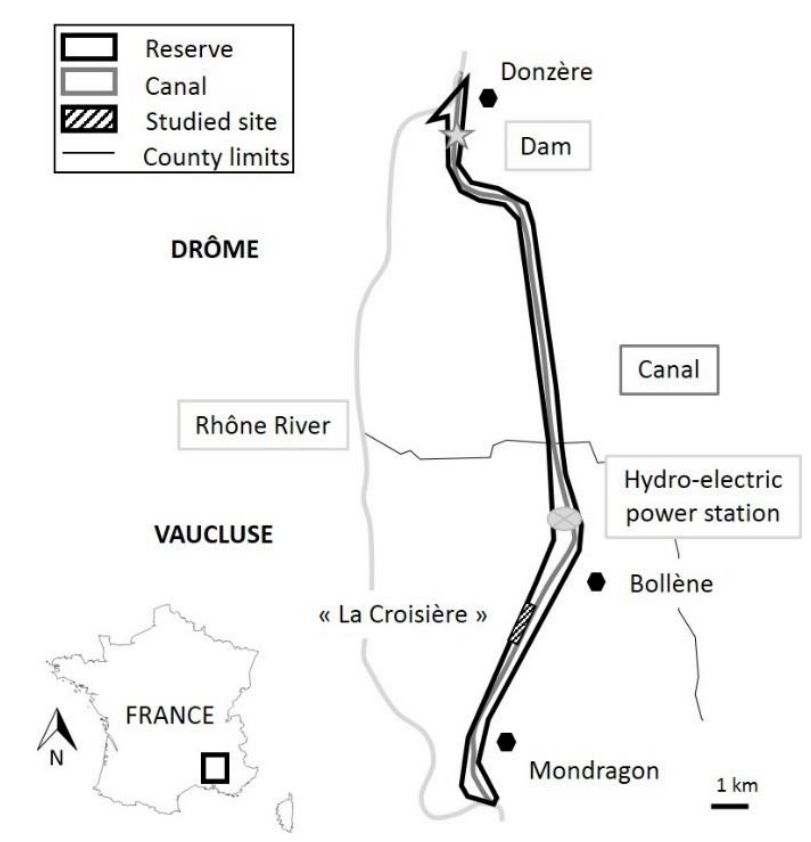

Figure 1. Localisation of the study site La Croisière at the level of the Donzère-Mondragon hydroelectric power station in the lower Rhone valley (South-East France). Localisation of study sites (dots), boundaries of the reserve (black line), hydroelectric power station (light grey dots), canal (dark grey line), the Rhone (light grey line).

The dykes and embankments were constructed with millions of tons of alluvial sediment (stones, sand, silt) extracted from the excavation of the canal, and were planted with ornamental trees for landscaping purposes. In February 1954, a hunting reserve and wild fauna were established, managed by the Office National de la Chasse et de la Faune Sauvage, over an area of $1454 \mathrm{ha}$, along a $28 \mathrm{~km}$ strip with a width of 300 to $850 \mathrm{~m}$. The goal was to increase the numbers of game species and the diversity of habitats for the flora and fauna (Roux et al. 2007).

In 2014, a 50-ha site was chosen to test the impact of grazing on the forest vegetation. The site adopted, La Croisière, is situated $4 \mathrm{~km}$ south of the hydroelectric power station, on an embankment of the tailrace channel (Fig. 1). Initially planted with robinia in the 1950s in order to maintain the soils and speed up the natural vegetal succession by their action of fixing the atmospheric nitrogen, today the site thus possesses a dense canopy (95\%) composed of planted trees (Robinia pseudoacacia L.) or trees that have naturally colonised the site (Populus alba L., Populus nigra L., Fraxinus excelsior Vahl, Juglans regia L., etc.). Bramble (Rubus ulmifolius gr. Schott.) is the target species for the system of management applied at the site. This species, whose colonisation dynamics are facilitated by alterations in the regimes of disturbance an/or the environmental conditions (Masson 2014), is widespread in the Mediterranean region. The vegetation was mechanically cleared in 2012 via a system of cleared paths linking clearings, then grazing by Rove goats was introduced from 2013 in an area of 20 ha in the middle of the site. 
The Rove goat is a rustic breed that is widely used in the shrubland pastures of the south of France, in particular in the Provence-Alpes-Côte-d'Azur region. During the transhumance of sheep in Provence Rove goat is used as a bellwether for the flock, and to suckle twins or orphans. In addition, it contributes to the herder's food resources (goat's milk and meat). Although this breed almost disappeared, the number of individual is strongly increasing again today (less than 200 in the years 1830, 7918 in 2010, respectively), (Duclos 2010). This mixed breed (providing both milk and meat) shows a good aptitude to valorise harsh environments because of its rusticity (low sensitivity to strong variations in temperature, aptitude to move in rugged areas and benefit from them). Thus, the Rove goat is regularly used for brush clearing.

The goat herd belongs to entrepreneur shepherds specialised in eco-grazing, without the objective of milk or meat production. Between July and October 2013, 300 goats Rove goats were present on the site, but only about 100 during the same period in 2014 and 2015. In 2016, a hundred goats and sheep were present from March to October. In 2017, the arrival of goats later than the suitable period of vegetation made it impossible to carry out the monitoring. During the grazing period a goatherd was present and the herd was guided by dogs during the day. At night the herd was retained in mobile enclosures whose location changed at each grazing season in order to reduce the risk of infection by short-cycle parasites, and to optimise the action of consumption by the herd over the whole site.

\begin{tabular}{|c|c|c|c|c|}
\hline Year & Animals & Numbers & $\begin{array}{l}\text { Duration of grazing } \\
\text { (months) }\end{array}$ & LU/ha/year \\
\hline \multirow{2}{*}{2013} & Goats & 300 & 4 & \multirow{2}{*}{0.96} \\
\hline & Sheep & 180 & 2 & \\
\hline \multirow{3}{*}{2014} & Goats & 89 & 4 & \multirow{3}{*}{0.37} \\
\hline & Female kids & 9 & 4 & \\
\hline & Sheep & 164 & 1.2 & \\
\hline \multirow{2}{*}{2015} & Goats & 95 & 5.33 & \multirow{2}{*}{0.32} \\
\hline & Male kids & 20 & 0.75 & \\
\hline \multirow{3}{*}{2016} & Goats & 94 & 6 & \multirow{3}{*}{0.53} \\
\hline & Male kids & 30 & 6 & \\
\hline & Sheep & 40 & 2.5 & \\
\hline 2017 & Goats & 280 & 2 & 0.35 \\
\hline
\end{tabular}

Table 1. Calculation of goat grazing load since the introduction of the herd at the La Croisière site (20 ha). Numbers, LU (Livestock Unit) and duration of the presence of the animals at the site are specified.

\subsection{Survey of the vegetation}

Out of the 50 ha of the site, around 15 ha were cleared in 2012 in the form of cleared paths linking clearings, and an area of 20 ha is grazed since 2013. It was possible to test four treatments - goat grazing alone (G: grazed), brush clearing and grazing (CG: cleared and grazed), clearing and exclusion of grazing (CF: cleared and fenced) and control without management (C: control). For each treatment five plots of $100 \mathrm{~m} 2(10 \times 10 \mathrm{~m})$ were replicated and randomized.

The survey was carried out using quadrats whose size was determined by the calculation of the minimum area (Guinochet 1973) of shrub and tree plant communities: $25 \mathrm{~m} 2(5 \times 5 \mathrm{~m})$. Each quadrat was positioned in the centre of each plot ( $N=20: 4$ treatments $\times 5$ quadrats) to prevent edge effects from the borders especially in the $\mathrm{CF}$ treatment which were fenced.

The abundance of each plant species was defined in coverage classes, as follows: 1 = species covering less than $5 \%$ of the quadrat, 2 = species covering between 5 and $25 \%, 3=$ species covering between 26 and $50 \%, 4=$ species covering between 51 and $75 \%, 5=$ species covering more than $75 \%$, and $+=$ species representing the only individual within the quadrat.

The monitoring of the vegetation was carried out each year in May (2014 to 2016), a period when the majority of plant species are identifiable. Species-richness (number of species for $25 \mathrm{~m} 2$ ) and similarity, which corresponds to the mean of the Bray-Curtis distance between the five quadrats for each of the five plots in each treatment (the mean of the distance varies from 0 to 1,0 signifying a total similarity between the treatments), were calculated. We 
also recorded vegetation height $(\mathrm{cm})$. The nomenclature of vascular plants follows that of Tison et al. (2014).

\subsection{Estimation of Goat consumption of brambles}

Since the bramble is the dominant species of the shrub stratum (Rocher 2014), it was designated by the reserve managers as the target species to control in order to assess the success of the operation. Three assessment surveys of the consumption by goats were, therefore, carried out. To assess the consumption, surveys were carried out at the end of each period of grazing (winter), in 2015, 2016 and 2017, with the aim of comparing the rate of consumption of the brambles according to the distance from the mobile enclosure, and whether or not clearing had been undertaken. For each survey, the percentage of goat consumption of the brambles (leaves, twigs, young shoots, Tab. 2) was estimated according to the protocol proposed by Garde et al. (2013). The absence of consumption or the absence of brambles at the survey point were also recorded. Class 1 was assigned to a bramble consumption between 0 to $10 \%$. In the same way, class 5 was assigned to a bramble consumption superior to $60 \%$.

\begin{tabular}{cc}
\hline Index & Consumption by goats $(\%)$ \\
\hline$\varnothing$ & Absence of brambles \\
+ & Total absence of consumption \\
1 & $1-10$ \\
2 & $10-20$ \\
3 & $20-40$ \\
4 & $40-60$ \\
5 & $>60$ \\
\hline
\end{tabular}

Table 2. Index of consumption of bramble (Garde et al., 2013, modified). For each survey, the absence of bramble and the absence of consumption by goats were notified. Class 1 means a consumption between 1-10 $\%$ of bramble, class 5 shows a consumption of $60 \%$ and more.

The estimation of the consumption of brambles and the presence of bite marks were measured by a group of eight people, four to the north of the access track (Fig. 4) and four to the south, one person covering the lower part of the slope, two the middle and one the upper part of the slope. The survey points referenced by GPS (index of consumption) were located roughly every $20 \mathrm{~m}$, along straight transects, as far as the boundary of the grazed area (20 ha total area). If a point previously referenced was not accessible to the observer (presence of impenetrable brambles), one point was then referenced at the beginning of the obstacle and another at the end. This method was chosen because it was impossible to use aerial photography because of the very high vertical heterogeneity of the understorey vegetation.

The woody plants, including the brambles, can tolerate up to $30 \%$ of consumption of their organs. Beyond that, regeneration decreases and the resource is depleted (Tab. 3, Garde et al. 2013). Thus a higher rate of consumption than this $30 \%$ was targeted at the scale of the study site.

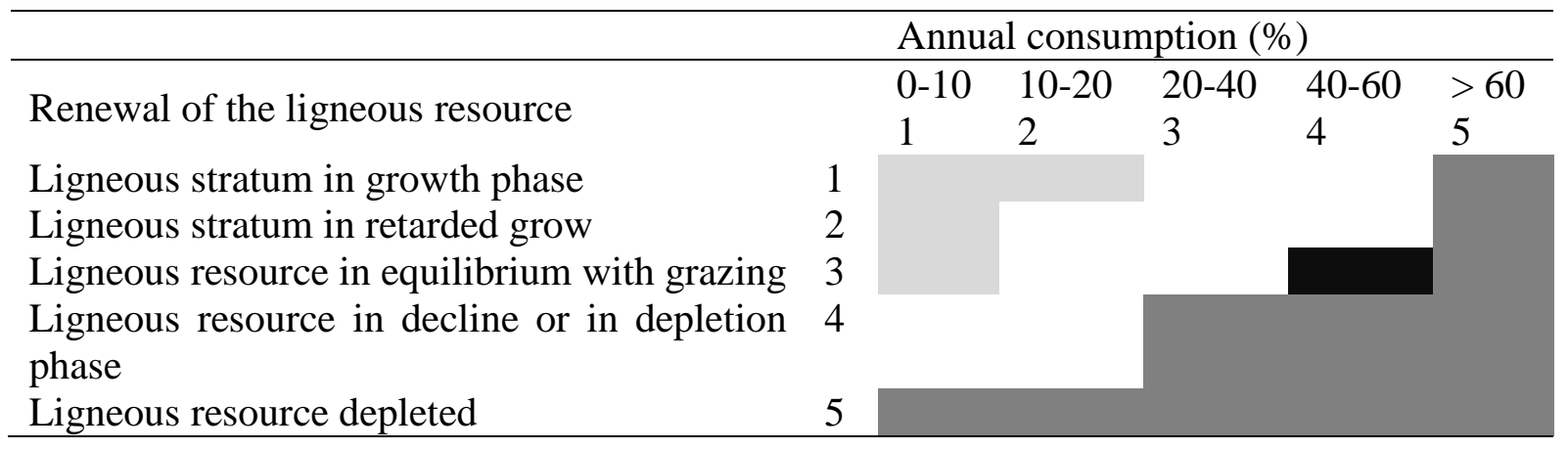

Table 3. Assessment grid for the consumption of ligneous species adapted for the site target species: the bramble. After Garde et al. 2013, modified. 
A map of the annual consumption of the bramble by goats at the end of the grazing season was drawn using the software ArcGis 10.2, using the principle of spatial interpolation of GPS points according to natural neighbours (prediction of the value of a point on the basis of values of points in the neighbourhood). The methods of interpolation are based on the principle of spatial autocorrelation, which assumes that the closer together the points are, the more they resemble each other (ESRI 2004).

\subsection{Statistical analyses}

Linear Models (LM) were used to analyse the effects of the various treatments applied to the vegetation. The treatments (CG, CF, G and C) and the years of monitoring (2014, 2015 and 2016) are considered as factors and the properties of the vegetation as variables. A second Linear Model was performed with brush clearing or not and the year $(2015,2016,2017)$ as factors and the consumption of brambles by goats as variable.

In order to characterise the changes in the composition and the distribution of the vegetation, and the correlations between the species and treatments, the characteristics concerning the composition and the abundance of the plant species were ordinated using NMDS (Non-Metric Multidimensional Scaling) based on the index of similarity of BrayCurtis (Borcard et al. 2011).

To compare the height of the vegetation, the richness in species, the Bray-Curtis distance, we used ANOVA tests for multiple comparisons when the data followed a normal law (tests of Shapiro-Wilk or Lilliefors). A Tukey post-hoc test followed this first analysis when a significant difference was detected between the treatments. We used t tests for two-by-two comparisons, notably to bring out difference in goat consumption of brambles between the cleared or not cleared areas. When the data did not follow a normal pattern of distribution, we used a Wilcoxon or KruskalWallis non-parametric test, followed by a Mann-Whitney-Wilcoxon non-parametric test, where the value of $p$ was adjusted according to the method of Benjamini and Hochberg (1995). When a difference was detected between treatments, we performed a two-by-two using Mann-Whitney-Wilcoxon tests.

Spearman correlations between the distance from the mobile enclosures and the bramble consumption indices were calculated for each year.

All the statistical analyses were performed using the version of the software R 2.15.3. (The R Foundation for Statistical Computing 2012), using its native packages for the univariate analyses and the supplementary packages ade4 (Chessel et al. 2004; Dray \& Dufour 2007) and vegan (Oksanen et al. 2012)for the multivariate analyses (ACP and NMDS).

\section{Results}

\subsection{Vegetation}

The number of herbaceous species increased between 2014 and 2015. Nevertheless, the total number of plants recorded declined in 2016, but remained higher than in 2014 (2014:63 species, 2015:76 species, and 2016:67 species). The most frequently occurring species in the vegetation surveys, all treatments taken together, were: Hedera helix L., Rubus ulmifolius gr., Brachypodium sylvaticum (Huds.) P.Beauv., Crataegus monogyna Jacq., Cornus sanguinea L. and Clematis vitalba L., present in more than $75 \%$ of the quadrats. The least frequent herbaceous species are the annual species such as Bromus hordeaceus L., Artemisia annua L. and Lysimachia arvensis (L.) U.Manns \& Anderb. (Appendix 1). The NMDS analysis (stress NMDS $=0.13$ ) performed on the data (20 quadrats $\times 67$ species) from the last year (2016, Fig. 2A) revealed evidenced differences in the vegetation composition between the different treatments applied (grazing, clearing, grazing + clearing). The control with no management was characterised by liana-bearing, shrub or tree species (Hedera helix, Juglans regia, Cornus sanguinea, Crataegus monogyna and Populus alba). The cleared and grazed quadrats (CG) were rather dominated by herbaceous species (Brachypodium sylvaticum, Anisantha sterilis (L.) Nevski, Torilis arvensis (Huds.) Link, Erigeron sp., Verbena officinialis L.). The treatments non-cleared and grazed (G) and cleared in 2012 then fenced from 2013 (CF) possessed the same plant composition but with shrub or liana-bearing species still present or having regenerated (Robinia pseudoacacia, Rubus ulmifolius gr., Clematis vitalba). After three years of monitoring, the trajectory of the barycentre of the treatment polygons between the survey years 2014 to 2016 (Fig. 2B) characterised a common direction of vegetation dynamic of the grazed $(G)$ and cleared and grazed (CG) treatments. In the no-management control (C) the trajectory of the polygons went in the opposite direction. The cleared then fenced treatments (CF) had another trajectory from those of the other three treatments. 
A
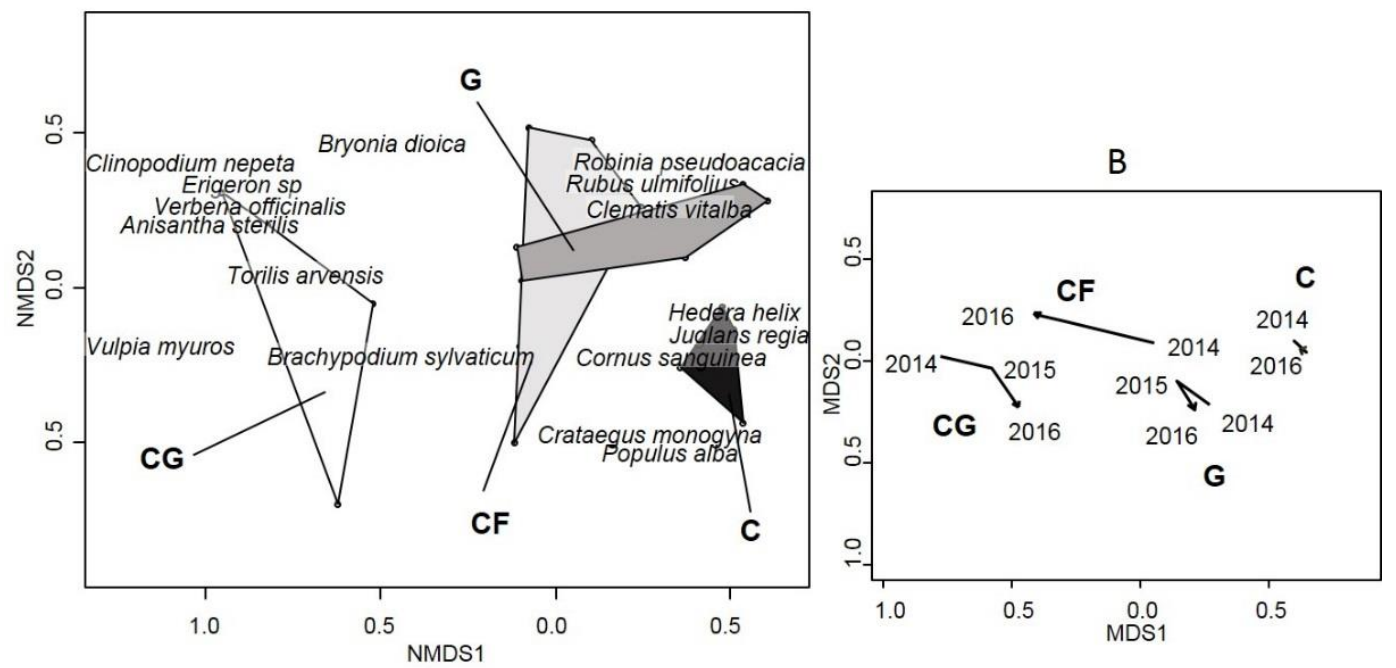

Figure 2. NMDS ordination (NMDS stress $=0.13)$ based on 20 vegetation survey quadrates $x 67$ species situated on the embankment of the tailrace canal of Donzère-Mondragon (SE France). Figure A represents the recordings of the last year of the survey (2016) grouped by treatment (polygons): cleared and grazed by goats $(C G)$, cleared and fenced $(C F)$, non-cleared and grazed $(G)$ and non-cleared non-grazed $(C)$. To simplify, only the plants with the closest correlation with the first axes are shown. B shows the dynamic of the vegetation for each treatment, according to the position of their barycentre during the three years of the vegetation survey (2014-2016).

The Linear Models (Tab. 4) showed highly significant effects of the management treatments on the mean height of the vegetation $(p<0.01)$, the species-richness and the Bray-Curtis index $(p<0.001)$. There was no significant effect of the year on the vegetation parameters measured and the interaction treatment $x$ year.

\begin{tabular}{|c|c|c|c|}
\hline Parameters & $\begin{array}{l}\text { D } \\
\text { f }\end{array}$ & F value & p value \\
\hline \multicolumn{4}{|c|}{ Mean vegetation height } \\
\hline Treatment & 3 & 4.931 & $* *$ \\
\hline Year & 2 & 0.746 & NS \\
\hline Treatment : year & 6 & 1.851 & NS \\
\hline \multicolumn{4}{|c|}{ Species richness } \\
\hline Treatment & 3 & 27.804 & $* * *$ \\
\hline Year & 2 & 1.2564 & NS \\
\hline Treatment : year & 6 & 1.735 & NS \\
\hline \multicolumn{4}{|c|}{ Bray-Curtis index } \\
\hline Treatment & 3 & $\begin{array}{c}135.62 \\
1\end{array}$ & $* * *$ \\
\hline Year & 2 & 2.499 & NS \\
\hline Treatment : year & 6 & 2.201 & NS \\
\hline
\end{tabular}

Table 4. Results of Linear Models testing the effects of the treatments applied (grazing and/or clearing), the survey years (2014-2016) and their interaction on four situations managed in a different way at the site of La Croisière in the lower Rhone valley: $p<0.001 * * *, p<0.01 * *, p<0.05 *$, Non-significant NS).

In 2014 and 2015, no significant difference in the mean height of the herbaceous vegetation was recorded between the different treatments (Fig. 3A). In 2016, the CG height was significantly lower than in CF and G, (Fig. 3A). In 2015, high heterogeneity in the height of the vegetation between quadrats was observed for the grazed only treatment. 
The species richness was then significantly higher in CG than the control, and higher than in all the other treatments in 2016 (Fig. 3B). In 2015 as in 2016, the species-richness of CF, or G were not significantly different from the nomanagement control (Fig. 3B). In 2014, the Bray-Curtis index was significantly higher in the managed quadrats compared to the control (Fig. 3C). In 2015, the heterogeneity index in CG and CF were significantly higher than the two others (G, C) of. In 2016, only CG was significantly higher (Fig. 3C).
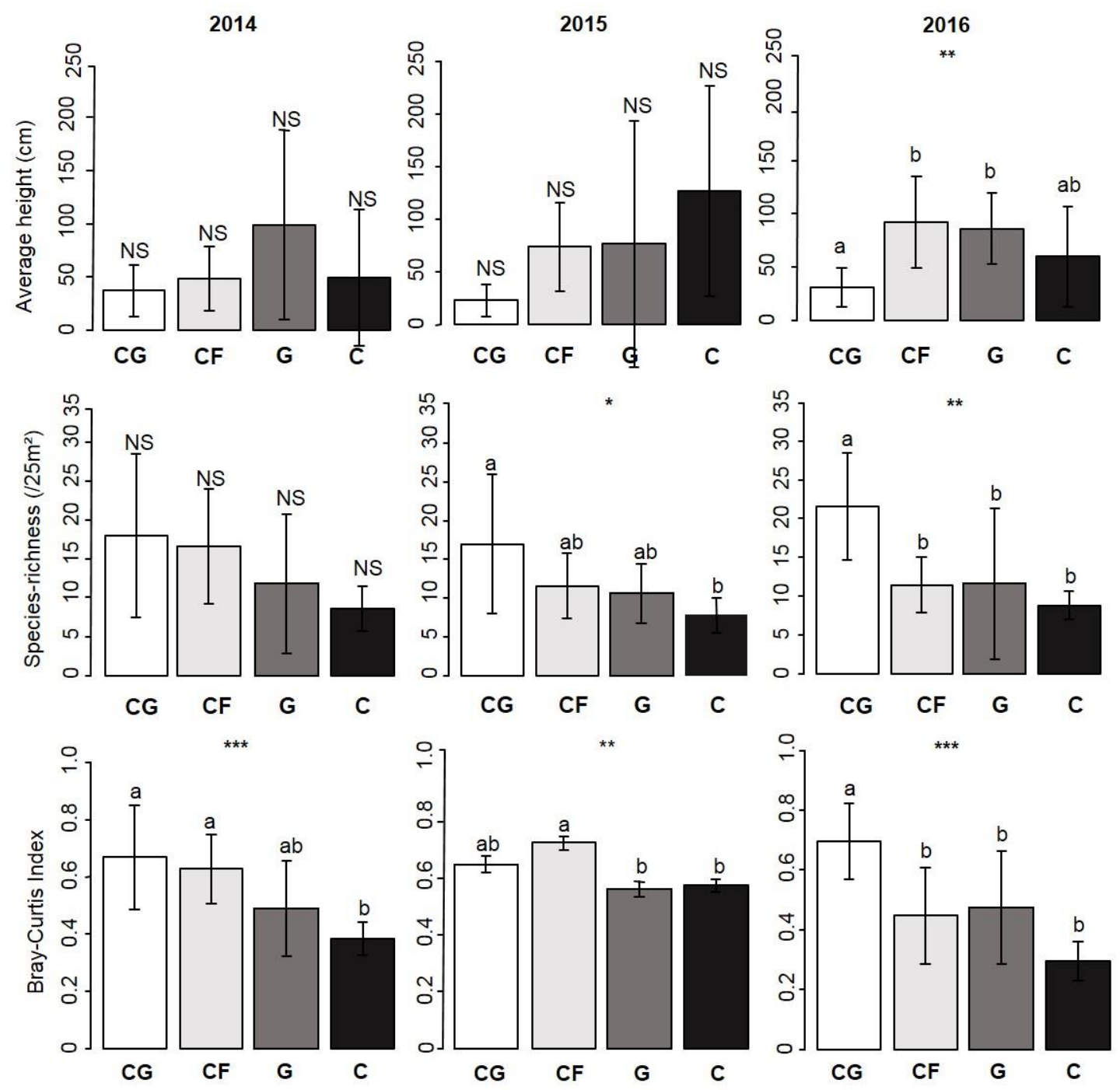

(C)

Figure 3. Means and standard errors of the mean height (A), the species-richness $(B)$ and the Bray-Curtis index in the $25 \mathrm{~m}^{2}$ quadrates in 2014, 2015 and 2016, at the site grazed by goats and/or cleared and grazed by goats (site of La Croisière, Donzère-Mondragon): cleared and grazed by goats (CG), cleared and fenced $(C F)$, non-cleared and grazed by goats $(G)$, non-cleared and non-grazed $(C)$. The bars possessing letters in common show no significant difference between treatments for the same year, according to the Tukey post-

hoc test

\subsection{Estimation of Goat consumption of brambles}

The indices of consumption measured each year at the end of the grazing season (Fig. 4) provided a basis for estimation of the goat consumption of brambles at the site scale. In 2015, the highest rates of consumption of brambles (40-60\%) was mainly situated at the north of the mobile enclosures. At the south of the mobile enclosures, the consumption rarely exceeds $10-20 \%$ of the quantity measured. Overall, the site appeared to be relatively little grazed ( $15 \%$ of the consumption on average), with a heterogeneous grazing pressure. The consumption action of the goats was mainly exerted in the vicinity of the mobile enclosures.

In 2016, the shifting of the mobile enclosures to the top of the embankment led to an increase in the grazing stocking rates (40-60\% of the consumption). Nuclei of consumption higher than $60 \%$ were visible. The year 2016 
corresponded to the longest period of presence of the herd (six months) and an earlier arrival in the season (from March) than in 2015 (Tab. 1).

In 2017, although the herd only remained for two months, the higher stocking density ( $0.35 \mathrm{LU} / \mathrm{ha} / \mathrm{year}$ ) allowed a high impact on bramble (40-60 \% of consumption). However, this high impact only concerned a small area of the site (Tab. 1).

When the area was cleared in 2012, the goat consumption of brambles increased significantly. Whatever the year (2015-2017), the mean goat consumption of bramble in the cleared paths and clearings was higher than in the noncleared areas. The Linear Model performed revealed that the cleared or not cleared treatment and the year of sampling had a significant impact on the consumption of bramble by goats ( $F$ value $=14.073, \mathrm{df}=1, p<0.001 ; \mathrm{F}$ value $=348.831, \mathrm{df}=2, \mathrm{p}<0.001$, respectively $)$ and there was a significant interaction between the two factors $(\mathrm{F}$ value $=$ $3.174, \mathrm{df}=2, \mathrm{p}<0.05)$.

\begin{tabular}{ccccc}
\hline $\begin{array}{c}\text { Survey } \\
\text { years }\end{array}$ & $\begin{array}{c}\text { Statistic } \\
\text { parameters }\end{array}$ & $\mathrm{p}$ value & $\begin{array}{c}\text { Cleared } \\
\text { vegetation }\end{array}$ & $\begin{array}{c}\text { Non-cleared } \\
\text { vegetation }\end{array}$ \\
\hline 2015 & $\mathrm{~W}=17470$ & $\mathrm{p}<0.001$ & $30.17 \pm 1.86 \%$ & $27.67 \pm 1.77 \%$ \\
2016 & $\mathrm{~W}=12320$ & $\mathrm{p}<0.05$ & $31.35 \pm 2.02 \%$ & $22.92 \pm 2.15 \%$ \\
2017 & $\mathrm{~W}=11252$ & $\mathrm{p}<0.01$ & $38.36 \pm 2.30 \%$ & $30.12 \pm 1.92 \%$ \\
\hline
\end{tabular}

\section{Table 5. Results of bramble goat consumption in cleared and non-cleared vegetation at the site of La Croisière, Donzère-Mondragon: survey years (2015-2017), results of Wilcoxon test, $p$ value and mean consumption \pm stand error are indicated.}

The rate of $30 \%$, beyond which the regeneration of the above-ground biomass is compromised, was only reached in the cleared paths and clearings in 2015 and 2016. This rate was only reached in 2017 in the non-cleared areas (45\% of the surface area).

In 2015, two mobile enclosures were installed on the site (Fig. 4) in its centre. The same results were then recorded for the two areas, the goats' consumption of brambles was thus negatively correlated to the distance from the mobile enclosures (first: Rho $=-0.38, \mathrm{p}<0.001$; second: $\mathrm{Rho}=-0.35, \mathrm{p}<0.001, \mathrm{~N}=370$ points GPS). In 2016, these two mobile enclosures. The results were similar to those of 2015 , with a significant negative correlation between brambles and the distance from the mobile enclosures, but higher for the first mobile enclosure (the southernmost, Fig. 4), (Rho $=-0.56, p<0.001$, for the first mobile enclosure and Rho $=-0.28, p<0.001$ for the second, $N=299$ points GPS). In 2017, only one mobile enclosure was installed, but the result remains identical to those of the preceding years, with a significant negative correlation between the distance from this mobile enclosure and goats' consumption of brambles (Rho $=-0.32, \mathrm{p}<0.001, \mathrm{~N}=313$ GPS points). 

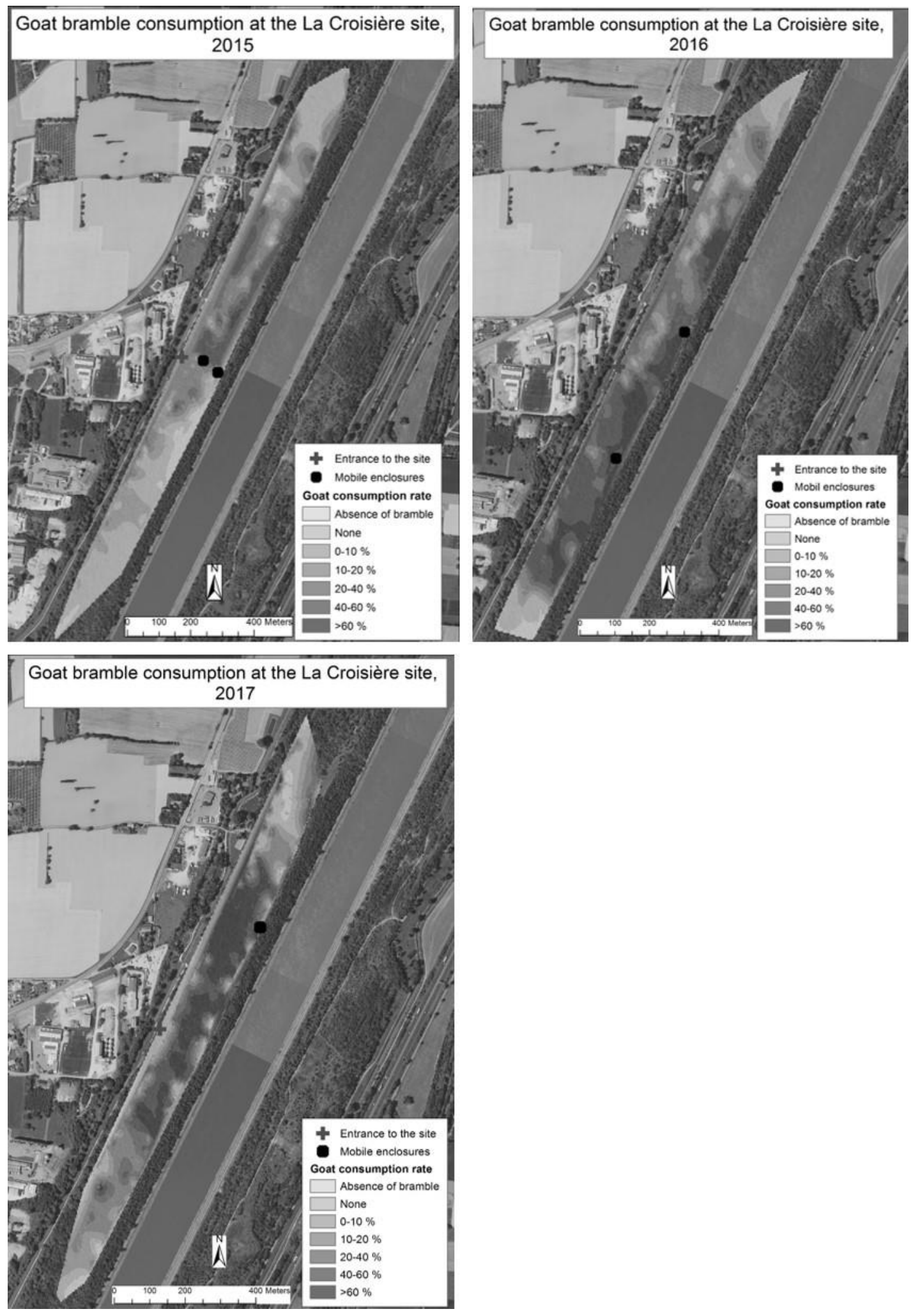

Figure 4. Map showing the estimation of the bramble consumption by Rove goats at the La Croisière site (Donzère-Mondragon) at the end of the grazing season in 2015, 2016 and 2017 (from left to right). The percentage of bramble consumption is shown in gradations of red. The position of the mobile enclosure is represented by a black symbol. () BD Ortho $50 \mathrm{~cm} 2015$ French National Institute of Geographic and Forest Information (IGN). 


\subsection{Impact of the three types of conservation management on the vegetation}

As already shown in various natural environments (Bakker 1989), brush clearing followed by goat grazing led to an increase of the species richness and of the heterogeneity of the herbaceous vegetation. It has been also the case in our artificial environment in three years only. The presence of brambles is known to reduce the plant diversity (McEvoy et al. 2006; Masson, Gauvain, et al. 2015; Masson, Mesléard, et al. 2015), because of its competition for light with certain herbaceous species (van Uytvanck et al. 2008). Mechanical clearing eliminates most of the main branches and stimulates the growth of young branches which in return are strongly consumed by goats, as they are highly appetising (Ingham 2008). The decline in height and coverage of the brambles by mechanical clearing or goat grazing (Barbaro et al. 2004) may then be of benefit for other species since a higher quantity of light then becomes available. The combination of cutting and grazing enabled a significant opening up of the environment. The increase in light at the ground level (Radosevich et al. 2007) combined with the reduction of competition (McEvoy et al. 2006) allowed the germination of other species. In our study, there was no significant effect of the year on the vegetation parameters measured and the interaction between treatment applied and year. Consequently, the analysis of the differences between the types of management tested and the descriptors of the plant communities encountered is meaningful in our study. The success of grazing was also due to the way the goats browse, notably by stripping the plants of their leaves, consuming large portions of the stems and digging up the shallowest roots (Stein \& Fosket 1969). The higher Bray-Curtis index in 2016 for the cleared and grazed treatment reflects this heterogeneous action of the herd on the vegetation.

\subsection{Impact of the two management types on the bramble cover}

The aim of combining the two types of management on this site was to open the vegetation and to specifically reduce the bramble cover on this artificial embankment yet strongly colonised by this species. Our results show that previous clearings led to a higher goat consumption of bramble. During the three years of monitoring, the grazing pressure slightly differed, thus the method used by the goatherd to manage the herd, the duration of the grazing and the distribution of the mobile enclosures are the main variables explaining the differences in the goats' consumption rates. In 2015 , the site was not grazed in its entirety (20 ha) or in a homogeneous way, whereas in 2016, the animals were guided across the site. Furthermore, they arrived early in the season. The mobile enclosures were also placed to maximise the bramble consumption rate over the whole site. In 2017, the duration of the animals' presence was three times shorter, but their impact on the bramble was only slightly lower than in 2016. Various studies have already reported the conclusive utilisation of goats to control brambles (McGregor 1996). The effective control of a target species consists in matching the herbivore to the target plant in terms of palatability and grazing the animals at the frequency and intensity which will do most damage to the plant (Olson \& Launchbaugh 2006). The goats select the most appetising young resprouts of branches, the nourishing young leaves, which may in the end prevent flowering and consume the meristematic tissues of the plants (Ingham 2008). Thus, certain studies claim that 18 months may be enough when the grazing load is correctly adjusted, so that the goats control the brambles (McGregor 1996). Furthermore, the leaves of the shrubs are often selected by these animals because their possess more proteins and less fibres than the leaves and stems of herbaceous plants (Holechek et al. 1989; Papachristou \& Nastis 1990).

\subsection{Implications for the management of the vegetation of embankments}

The utilisation of a herd of goats for eco-grazing or brush clearance is becoming more and more frequent, as a complement or not to mechanical clearing. On our study site, these two modes of management combined have enabled the expression of a wider diversity and heterogeneity of the herbaceous vegetation. The presence of an experienced goat herd leading his herd as on our site in 2017, when the impact on the brambles proved to be the strongest, and stimulating the motivation of the herd throughout the day of grazing (Meuret 2005), appears a necessity. The early arrival of a herd (from March in our case) would also constitute an advantage since it is the period of bud break for bramble in the Mediterranean region. Grazing after the beginning of flowering does more damage to the plant by removing the stems which contain energy and stored nutrients (Hendrickson \& Olson 2006). In contrast, the cessation of grazing and clearing led to the development of robust, high colonising species and reduced the species-richness in herbaceous plants.

The setting up of mobile enclosures should be planned ahead of the experiment as it leads to a higher grazing pressure in its neighbourhood, as recorded on the site of Donzère-Mondragon.

The distribution of grazing schemes can be improved over time by training and animal selection (Roath \& Krueger 1982; Walker 1995) which is an argument in favour of keeping the same herd from year to year. At the study site, 
two different herds grazed. Keeping the same herd also means the establishment of pluri-annual contracts with the farmers, which favours the sustainability of their activity. The grazing stocking rate must obviously be adjusted according to the specific characteristics of the site (surface area, above ground biomass of brambles and of target species present, etc.). A perfectible adjustment can, in particular with goat, be problematic as goat is sometimes condemned for causing damage to habitats (Peacock \& Sherman 2010). Elias and Tischew, (2016) propose three practical rules to respect or to keep in mind when we want to use goat to graze in the understorey: food supplements should be strictly avoided (except minerals); the goats' impact on the brambles is higher when the bushes do not exceed a height of $2 \mathrm{~m}$ and, in this case, no mechanical cutting of the shrubs is necessary; if the brambles are higher, their mechanical removal before the beginning of the grazing will enhance the success of the process.

Numerous studies have shown the positive effects of grazing on biodiversity (De Cauwer \& Reheul 2009; D'Aniello et al. 2011), of clearing (Wahlman \& Milberg 2002; Tälle et al. 2015), and of the combination of the two types of management (Kahmen et al. 2002; Saarinen \& Jantunen 2005). On the site of Donzère-Mondragon, the complementarity of the utilisation of goat grazing and mechanical clearing has made possible the enhancing of biodiversity and the control of bramble encroachment. Nevertheless, the combined application of mechanical clearing and grazing is not always effective for controlling the spread of R. ulmifolius gr. (Masson 2014). The application of mechanical clearing should comply with several rules. The specific conditions of a site are important to determine the appropriate intensity of mechanical control (Tälle et al. 2018). The repetition over the years of mechanical clearing tends to shift the plant community towards an assemblage of perennial species, by favouring the retention of nitrogen (Maron \& Jefferies 2001). The organic matter left in place favours the enrichment of the soil. Here again, depending on the management goals that have been determined, the exportation of the products of the clearing might be envisaged. The cost of mechanical clearing must be taken into account when the choice of the appropriate management method to apply is uncertain.

\section{Acknowledgements}

We thank the Compagnie Nationale du Rhône (CNR), the owner of the site, and the Office National de la Chasse et de la Faune Sauvage (ONCFS), the manager of the site, for their financial support. We also thank SFR Tersys for the prize awarded in 2014. Our thanks are due to Bruna Romanini for the construction of the exclosures at the site, Romain Brusson (CNR) and Denis Roux (ONCFS) for access to the site. We warmly acknowledge the technical assistance received from Jean-François Alignan, Anne Aurière, Jordan Batikh, Olivier Blight, Julie Chenot, Anouk Courtial, Marthe Lucas, Daniel Pavon, Arthur Rocher and Christel Vidaller, for the botanical inventories and estimations of the goat consumption rate. We thank the two anonymous reviewers for their useful comments.

Declaration of interest: The authors declare that they have no conflict of interests.

\section{References}

- Bagella S, Caria MC, Farris E, Rossetti I \& Filigheddu R (2016) Traditional land uses enhanced plant biodiversity in a Mediterranean agro-silvo-pastoral system. Plant Biosystems. 150:201-207.

- Bakker JP. 1989. Nature Management by Grazing and Cutting: On the ecological significance of grazing and cutting regimes applied to restore former species-rich grassland communities in the Netherlands. Kluwer, Dordrecht: Springer Science \& Business Media.

- Bakker JP. 1998. The impact of grazing on plant communities. In: Grazing Conserv Manag. Dordrecht: Springer; $p$. 137-184.

- Barbaro L, Dutoit T, Anthelme F, Corcket E. 2004. Respective influence of habitat conditions and management regimes on prealpine calcareous grasslands. J Environ Manage. 72:261-275.

- Batâry P, Bâldi A, Sârospataki M, Kohler F, Verhulst J, Knop E, Herzog F, Kleijn D. 2010. Effect of conservation management on bees and insect-pollinated grassland plant communities in three European countries. Agric Ecosyst

Environ. 136:35-39. 
- Benjamini Y, Hochberg Y. 1995. Controlling the False Discovery Rate: A Practical and Powerful Approach to Multiple Testing. J R Stat Soc. 57:289-300.

- Bokdam J, Gleichman JM. 2000. Effects of grazing by free-ranging cattle on vegetation

- dynamics in a continental north-west European heathland. J Appl Ecol. 37:415-431.

- Borcard D, Gillet F, Legendre P. 2011. Numerical Ecology with R [Internet]. New York, NY:

- Springer New York; [cited 2018 Jan 18]. Available from:

- http://link.springer.com/10.1007/978-1-4419-7976-6

- Briefer EF, Haque S, Baciadonna L, McElligott AG. 2014. Goats excel at learning and remembering a highly novel cognitive task. Front Zool. 11:20.

- Bullock JM, Hill BC, Dale MP, Silvertown J. 1994. An Experimental Study of the Effects of Sheep Grazing on Vegetation Change in a Species-Poor Grassland and the Role of Seedling Recruitment Into Gaps. J Appl Ecol. 31:493507.

- [CERPAM]. Centre d'Etudes et de Réalisations Pastorales Alpes-Méditerranée. 2006. Pâturer la broussaille: connaître et valoriser les principaux arbustes des parcours du Sud de la France. [Grazing the shrubs: to know and to value the main shrubs of the courses of the South of France]. CERPAM.

- Chessel D, Dufour AB, Thioulouse J. 2004. The ade4 package - I : One-table methods. R News. 4:5-10.

- Clément B, Maltby E. 1996. Quelques facteurs de la biodiversité végétale dans les prairies humides des corridors fluviaux. [Some factors of plant biodiversity in wet meadows of river corridors]. Acta Bot Gallica. 143:309-316.

- D'Aniello B, Stanislao I, Bonelli S, Balletto E. 2011. Haying and grazing effects on the butterfly communities of two Mediterranean-area grasslands. Biodivers Conserv. 20:1731- 1744.

- De Cauwer B, Reheul D. 2009. Impact of land use on vegetation composition, diversity and potentially invasive, nitrophilous clonal species in a wetland region in Flanders. Agron Sustain Dev. 29:277-285.

- De Simiane M. 1987. Composition botanique et valeur alimentaire de la ration ingérée par les petits ruminants. [Botanical composition and nutritional value of the diet ingested by small ruminants]. In: For L'élevage En Région Méditerranéenne Fr. Gap: Louis-Jean; p. 167-183.

- Dray S, Dufour A-B. 2007. The ade4 Package: Implementing the Duality Diagram for Ecologists. J Stat Softw [Internet]. [cited 2018 Jan 18]; 22. Available from: http://www.jstatsoft.org/v22/i04/

- Duclos D. 2010. Race caprine du Rove, Répertoire 2010 des Eleveurs. [Goat breed of Rove, 2010 Breeders Directory]: Institut de l'élevage, Département Génétique - Service Aptitudes et Sélection des Races Laitières.

- Elias D, Tischew S. 2016. Goat pasturing-A biological solution to counteract shrub encroachment on abandoned dry grasslands in Central Europe? Agric Ecosyst Environ. 234:98-106.

- ESRI. 2004. ArcGis 10.2.

- Etienne M, Armand D, Grudé A, Girard N, Napoleone M. 2002. Des moutons en forêt littorale varoise. Cardère Editeur [Sheep in Var coastal forest].

- Frost RA, Launchbaugh K. 2003. Prescription grazing for rangeland weed management: a new look at an old tool. Rangelands. 25:43-47.

- Garde L, Brosse-Genevet E, Caraguel B, Dellavedova M, Romagny R, Senn O. 2013. Evaluation du pâturage sur 
parcours et alpages. [Evaluation of pasture on rangelands and alpine pastures Pastum]. 101:12-33.

- Gibson CWD, Watt TA, Brown VK. 1987. The Use of Sheep Grazing to Recreate Species-rich Grassland from Abandoned Arable Land. Biol Conserv. 42:165-183.

- Guinochet M. 1973. Phytosociologie. Masson.

- Hendrickson J, Olson B. 2006. Understanding Plant Response to Grazing. In: Target Grazing Nat Approach Veg Manag Landsc Enhanc. American Sheep Industry Association; p. 32-39.

- Holechek JL, Pieper RD, Herbel CH. 1989. Range and Management Principles and Practices. Englewood Clifs: Prentice-Hall Publ.

- Ingham CS. 2008. Himalayan blackberry (Rubus armenicus) and English ivy (Hedera helix) response to high intensity-short duration goat browsing [Internet]. Oregon: Oregon State University; [cited 2018 Feb 5].

- Jensen K, Trepel M, Merritt D, Rosenthal G. 2006. Restoration ecology of river valleys. Basic Appl Ecol. 7:383-387.

- Kahmen S, Poschlod P, Schreiber K-F. 2002. Conservation management of calcareous grasslands. Changes in plant species composition and response of functional traits during 25 years. Biol Conserv. 104:319-328.

- Köhler M, Hiller G, Tischew S. 2016. Year-round horse grazing supports typical vascular plant species, orchids and rare bird communities in a dry calcareous grassland. Agric Ecosyst Environ. 234:48-57.

- Langbein J, Siebert K, Nürnberg G. 2009. On the use of an automated learning device by group-housed dwarf goats: Do goats seek cognitive challenges? Appl Anim Behav Sci. 120:150-158.

- Lepš J. 1987. Vegetation dynamics in an early old field succession: a quantitative approach. Vegetatio 72:95-102. - Maron JL, Jefferies RL. 2001. Restoring enriched grasslands: effects of mowing on species richness, productivity, and Nitrogen retention. Ecol Appl. 11:1088-1100.

- Masson S. 2014. Du paysage à la population: impacts des changements d'usages et de la restauration face à la colonisation d'une espèce envahissante (Rubus ulmifolius Schott.) dans un écosystème substeppique méditerranéen. [From the landscape to the population: impacts of changes in uses and restoration in the face of the colonization of an invasive species (Rubus ulmifolius Schott.) In a Mediterranean subsystem ecosystem]. Université d'Avignon. - Masson S, Gauvain M, Mesléard F, Dutoit T. 2015. Impacts of water stress removal and disturbance regimes on Mediterranean dry grasslands diversity and succession. Plant Ecol. 216:1351-1369.

- Masson S, Mesléard F, Dutoit T. 2015. Using Shrub Clearing, Draining, and Herbivory to Control Bramble Invasion in Mediterranean Dry Grasslands. Environ Manage. 56:933-945.

- McEvoy PM, Flexen M, McAdam JH. 2006. The effects of livestock grazing on ground flora in broadleaf woodlands in Northern Ireland. For Ecol Manag. 225:39-50.

- McGregor B. 2003. Eco-grazing-the use of diversified grazing ecosystems as part of integrated weed management. Weed Soc Vic [Internet]. [cited 2017 Jul 12]. Available from: http://www.wpcln.org.au/wpcontent/uploads/2015/09/McGregor-2003-1st-Biennial-Conf-Weed-Soc-Vic-Ecograzing-to-control-weeds.pdf - McGregor BA. 1996. Using goats for the control of blackberries in northeastern Victoria. In: Melbourne; p. 321-4. - McNaughton SJ. 1985. Ecology of a Grazing Ecosystem: The Serengeti. Ecol Monogr. 55:259-294.

- Meuret M. 2005. Piloter la motivation alimentaire des herbivores sur milieux diversifiés : pour une éco-zootechnie des pratiques de pâturage. [To control the food motivation of herbivores in diversified environments: for an eco- 
zootechnical practice of grazing]. Université Aix-Marseille III: INRA.

- Meuret M, Bartiaux-Thill N, Bourbouze A. 1985. Evaluation de la consommation d'un troupeau de chèvres laitières sur parcours forestier, méthode d'observation directe des coups de dents, méthode du marqueur oxyde de chrome. [Evaluation of the consumption of a dairy goat herd on a forest path, method of direct observation of the teeth, method of the marker of chromium oxide]. Ann Zootech. 34:159-180.

- Nawroth C. 2017. Invited review: Socio-cognitive capacities of goats and their impact on human-animal interactions. Small Rumin Res. 150:70-75.

- Nicaise L. 1996. L'Herbivore, facteur d'augmentation de la diversité biologique des milieux artificiels: l'exemple des digues aménagées par la Compagnie Nationale du Rhône. [Herbivore, a factor increasing the biological diversity of artificial environments: the example of dykes developed by the Compagnie Nationale du Rhône]. Université de Rouen.

- Oksanen J, Kindt R, Legendre P, O'Hara B, Stevens MHH. 2012. The vegan Package

- [Internet]. Available from: http://cran.r-project.org/, http://r-forge.r - project.org/projects/vegan/

- Olson B, Launchbaugh K. 2006. Managing herbaceous broadleaf weeds with targeted grazing. In: Target Grazing Nat Approach Veg Manag Landsc Enhanc. : American Sheep Industry Association; p. 58-67.

- Papachristou TG, Nastis AS. 1990. Feeding behavior of goat in relation to shrub density and season of grazing in Greece. In: Toulouse.

- Peacock C, Sherman DM. 2010. Sustainable goat production-Some global perspectives. Small Rumin Res. 89:7080.

- Radosevich SR, Holt JS, Ghersa CM. 2007. Ecology of Weeds and Invasive Plants [Internet]. Hoboken, NJ, USA: John Wiley \& Sons, Inc.; [cited 2018 Feb 7].

- Reinke K, Jones S. 2006. Integrating vegetation field surveys with remotely sensed data. Ecol Manag Restor. 7:S18S23.

- Roath LR, Krueger WC. 1982. Cattle grazing and behavior on a forested range. J Range Manag.:332-338.

- Rocher A. 2014. Circuits de pâturage et ressources alimentaires des communautés végétales des digues et délaissés de la réserve de chasse et de faune sauvage de Donzère-Mondragon (Vaucluse et Drôme, France). [Grazing circuits and food resources of the vegetation communities of dykes and abandoned from the Donzère-Mondragon hunting and wildlife reserve (Vaucluse and Drôme, France)]. Avignon: IUT.

- Rogosic J, Pfister JA, Provenza FD, Grbesa D. 2006. Sheep and goat preference for and nutritional value of Mediterranean maquis shrubs. Small Rumin Res. 64:169-179.

- Rotherham ID. 2013. Trees, Forested Landscapes and Grazing Animals: A European Perspective on Woodlands and Grazed Treescapes [Internet]. [place unknown]: Routledge; [cited 2018 Jan 18]. Available from:

https://www.taylorfrancis.com/books/9780203102909

- Roudaut F, Aussibal G, Beylier B, Garde L, Gautier D. 2007. La broussaille, un atout pour le pâturage. [The scrub, an asset for grazing]. Rencontres Autour Rech Sur Rumin. 14:161-164.

- Roux D, Roux JP, Debiesse L. 2007. Donzère-Mondragon: la nature aux portes de l'urbain.... [Donzère-Mondragon: 
nature at the gates of the urban]. Faune Sauvage. 278:8-11.

- Saarinen K, Jantunen J. 2005. Grassland Butterfly Fauna under Traditional Animal Husbandry: Contrasts in Diversity in Mown Meadows and Grazed Pastures. Biodivers Conserv. 14:3201-3213.

- Saatkamp A, Henry F, Dutoit T. 2017. Vegetation and soil seed bank in a 23-year grazing exclusion chronosequence in a Mediterranean dry grassland. Plant Biosyst - Int J Deal Asp Plant Biol. 152:1020-1030.

- Seddaiu G, Bagella S, Pulina A, Cappai C, Salis L, Rossetti I, Lai R, Roggero PP. 2018. Mediterranean cork oak wooded grasslands: synergies and trade-offs between plant diversity, pasture production and soil carbon. Agroforest Syst. 92:893-908.

- Stein OL, Fosket EB. 1969. Comparative Developmental Anatomy of Shoots of Juvenile and Adult Hedera helix. Am J Bot. 56:546-551.

- Tälle M, Deâk B, Poschlod P, Valkó O, Westerberg L, Milberg P. 2016. Grazing vs. mowing: A meta-analysis of biodiversity benefits for grassland management. Agric Ecosyst Environ. 222:200-212.

- Tälle M, Deâk B, Poschlod P, Valkó O, Westerberg L, Milberg P. 2018. Similar effects of different mowing frequencies on the conservation value of semi-natural grasslands in Europe. Biodivers Conserv.:1-25.

- Tälle M, Fogelfors H, Westerberg L, Milberg P. 2015. The conservation benefit of mowing vs grazing for management of species-rich grasslands: a multi-site, multi-year field experiment. Nord J Bot. 33:761-768.

- Tison J-M, Jauzein P, Michaud H. 2014. Flore de la France méditerranéenne continentale. [Flora of continental Mediterranean France]: Naturalia Publications.

- Tolon V, Baubet E. 2010. L'effet des réserves sur l'occupation de l'espace par le sanglier. [The effect of reserves on the occupation of space by the wild boar]. Faune Sauvage.:14-18.

- Tôth E, Deâk B, Valkô O, Kelemen A, Miglécz T, Tôthmérész B, Török P. 2016. Livestock type is more crucial than grazing intensity: Traditional cattle and sheep grazing in short-grass steppes: Traditional cattle and sheep grazing in short-grass steppes. Land Degrad Dev.:

- van Uytvanck J, Maes D, Vandenhaute D, Hoffmann M. 2008. Restoration of woodpasture on former agricultural land: The importance of safe sites and time gaps before grazing for tree seedlings. Biol Conserv. 141:78-88.

- Wahlman H, Milberg P. 2002. Management of semi-natural grassland vegetation: evaluation of a long-term experiment in Southern Sweden. Ann Bot Fenn. 39:159-166.

- Walker JW. 1995. Viewpoint: Grazing management and research now and in the next millenium. J Range Manag.:350-357.

- Wasson JG, Malavoi JR, Maridet L, Souchon Y, Paulin L. 1995. Impacts écologiques de la chenalisation des rivières. [Ecological impacts of river channelization]. Lyon: Cemagref.

- Watkinson AR, Ormerod SJ. 2001. Grasslands, grazing and biodiversity: editors' introduction. J Appl Ecol. 38:233237.

- van Wieren SE. 1995. The potential role of large herbivores in nature conservation and - extensive land use in Europe. Biol J Linn Soc. 56:11-23.

- van Wieren SE, Bakker JP. 1998. Grazing for conservation in the 21st century. In: Grazing Conserv Manag. Vol. 11. Dordrecht: Kluwer Academic Publishers; p. 349-363. 
